$$
\begin{gathered}
\text { 측두골에 발생한 랑게르한스 세포 조직구증 } 2 \text { 예 } \\
\text { 동아대학교 의과대학 이비인후과학교실, }{ }^{1} \text { 병리학교실 }{ }^{2} \\
\text { 배우용 }^{1} \cdot \text { 장윤석 }^{1} \cdot \text { 홍숙희 }^{2} \cdot \text { 강명구 }^{1}
\end{gathered}
$$

\title{
Two Cases of Langerhans Cell Histiocytosis of the Temporal Bone
}

\author{
Woo-Yong Bae, MD ${ }^{1}$, Yoon-Seok Jang, MD ${ }^{1}$, Suk-Hee Hong, $\mathrm{MD}^{2}$ and Myung-Koo Kang, MD ${ }^{1}$ \\ ${ }^{1}$ Department of Otolaryngology-Head and Neck Surgery, ${ }^{2}$ Pathology, College of Medicine, \\ Dong-A University, Busan, Korea
}

\begin{abstract}
-ABSTRACT -
The most well-known childhood histiocytosis, previously known as histiocytosis $\mathrm{X}$, is Langerhans cell histiocytosis and includes the clinical entities of eosinophilic granuloma, Hand-Schüller-Christian disease and LettererSiwe disease. The hallmark of this disease is the presence of a clonal proliferation of cells of the monocyte lineage containing the characteristic electron microscopic findings of a Langerhans cell. The skeleton is involved in $80 \%$ of patients and bone lesions may be single or numerous and are seen most commonly in the skull, especially in the temporal bone. Prognosis is relatively favorable. We have experienced two cases of Langerhans cell histiocytosis with temporal bone involvement which were treated surgically in two children. ( $\mathbf{J}$ Clinical Otolaryngol 2005;16:132-135)
\end{abstract}

KEY WORDS : Histiocytosis, Langerhans-cell $\cdot$ Temporal bone $\cdot$ Surgery.

\section{서 론}

1941년 Farber ${ }^{1}$ 는 임상적으로 각기 다른 양상으로 나타나는 Hand- Schuller- Christian disease, Letterer- Siwe disease, Eosinophilic granuloma의 3가지 질환이 조직학적으로 비슷한 양상으로 나타난다고 발표 하였다. 그 후 1953년 Lichtenstein이 이 질환들을 하 나의 질환인 조직구증 $\mathrm{X}$ (histiocy tosis $\mathrm{X}$ )라고 명명하였 고, ${ }^{2)}$ 현재 랑게르한스 세포 조직구증(Langerhans cell

\section{논문접수일 : 2005년 4월 20일}

심사완료일 : 2005년 5월 30일

교신저자 : 강명구, 602- 715 부산광역시 서구 동대신동

3 가 1번지 동아대학교 의과대학 이비인후과학교실

전화 : (051) 240- 5428. 전송 :(051) 253- 0712

E- mail : mgkang@ daunet.donga.ac.kr histiocy tosis) 이라고 불리운다. ${ }^{34)}$ 이 질환은 골수 유래 의 단구 대식세포계(monocyte- macrophage system) 에 속하는 조직구가 과다증식을 초래하여 골, 피부, 점 막, 폐, 임파절 및 간 등의 장기를 침범한다. 이 중 골격 계 침범이 $80 \%$ 로 가장 흔하며, 골에 단독으로 발생하 거나 또는 다른 장기와 동시에 침범할 수도 있다. 골격 계 중에서는 두개골 침범이 가장 많으며 두개골에서는 측두골 및 전두골에 호발한다. ${ }^{3)}$ 저자들은 5 세 남아와 11세 여아의 측두골에 발생한 랑게르한스 세포 조직구 증 2예를 수술적 치료와 병합요법으로 치료하였기에 문 헌고찰과 함께 보고하는 바이다.

\section{증 례}

증 례 1:

5세 남아가 내원 1개월 전부터 시작된 우측 후이개부 
배우용 외 : 측두골에 발생한 랑게르한스 세포 조직구증 2예

의 $2 \times 2 \mathrm{~cm}$ 크기의 종창을 주소로 타병원에서 항생제 치료를 받았으나 크기 변화가 없었다. 측두골 전산화단 층촬영상 측두골 파괴 병변이 관찰되어 본원 이비인후 과로 전원되었다. 과거력 및 가족력상 특이 소견 없었고 이학적 검사상 우측 고막은 특이 소견이 없었으나, 우측 후이개부의 종창과 압통이 있었다. 순음청력검사상 양측 모두 정상 청력 범위 였다. 전산화단층촬영상 우측 측두 골의 인상부(squamous portion) 후상방에서 골을 파괴 시키는 연부 조직 음영이 있었고, 우측 유돌봉소 및 중 이강 내에 연부 조직 음영이 관찰되었으나 이소골, 안면 신경 및 내이의 구조물들은 잘 보전되어 있었다(Fig. 1). 우측 측두골의 병변 조직검사 및 유양돌기염 제거를 위 해 우측 단순 유양돌기 절제술을 시행하였다.

전신마취 하에 유양돌기 절제술을 시행하였고, 유돌봉 소와 유양돌기동에 육아조직들이 발견되어 제거하였다. 후두개와 경계 부위에는 붉은 색의 종물이 관찰되었고 일부가 뇌경막과 유착되어 일부를 절제하여 조직검사를 의뢰했다. 조직 병리학적 소견상 회선상의 둥근 핵을 가 진 조직구와 호산구, 림프구의 침윤이 관찰되었고, 면역 조직화학적 소견상 조직구는 CD1a와 S- 100 단백에 양 성반응을 보여 랑게르한스 세포임을 확인하였다(Fig. 2). 술 후 다발성 병변을 찾기 위해 시행한 골 주사검사, 골 수검사, 복부 초음파 및 간 주사검사 등에서 특이 소견
은 관찰되지 않았다. 잔류 병변을 제거하기 위해 측두골 부위에 방사선 치료를 시행하였고(600 rad/6일), 방사 선 치료 후 특별한 합병증 없이 퇴원하였다. 술 후 2년 6 개월째 시행한 자기공명영상에서 우측 측두골 내에 재 발이나 잔류종양의 소견은 보이지 않았으며 현재까지 특 별한 합병증은 관찰되지 않았다.

\section{증 례 2 :}

11세 여아가 내원 수년 전부터 시작된 양측 청력 감 소와 우측 이루 및 간헐적인 어지러움을 주소로 내원하 였다. 과거력 상 특이 소견은 없었고, 이학적 검사상 우 측 외이도에 종물이 관찰되어 시행한 조직검사에서 랑 게르한스 세포 조직구증으로 확진되었다. 우측 고막은 천 공은 없었으나 경미한 이루가 있었고, 좌측 고막은 정상 이었다. 순음청력검사상 골도 및 기도 청력역치는 좌측 은 각각 $10 \mathrm{~dB}, 35 \mathrm{~dB}$ 였고, 우측은 모두 $10 \mathrm{~dB}$ 였다. 측두골 전산화 단층촬영 상 우측 외이도에는 부분적인 골파괴 소견과 돌출되어 있는 종물이 보였고, 양측 유돌 봉소와 상고실 내에 커다란 연부조직 음영이 있었다. 또 한 양측 외반규관, 후반규관, 안면신경의 유돌 분절(mastoid segment)에 골미란(bony erosion)이 관찰되었 다. 자기공명영상에서 양측 유양돌기 부위와 중이강 부 위에는 T 2 강조영상에서 고신호강도, T1 강조영상에

Fig. 1. Preoperative temporal bone $\mathrm{CT}$ in case 1. It demonstrates osteolytic lesion on squamous portion. A : Axial view, B : Coronal view.
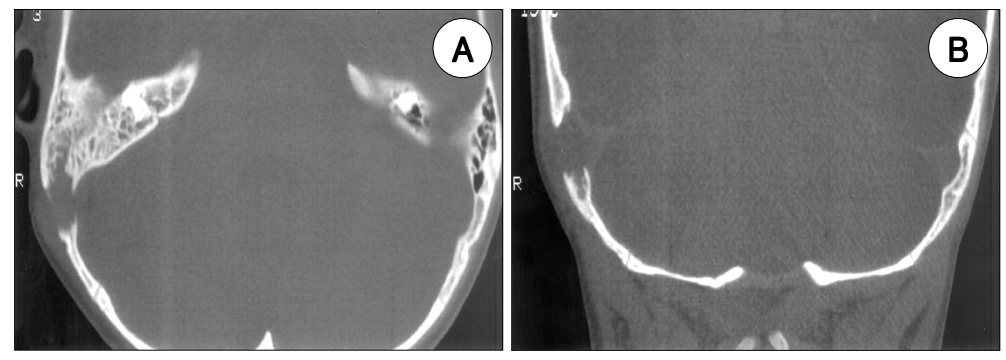

Fig. 2. Pathologic findings of Case 1. A : The osteolytic bone of case 1 shows infiltrates of histiocytes, eosinophils and multinucleated giant cells $(H \& E, \times 200)$. B : The immunohistochemical stain shows positive reaction of Langerhans cells for CDla (Immunohistochemical stain, $\times 200)$.
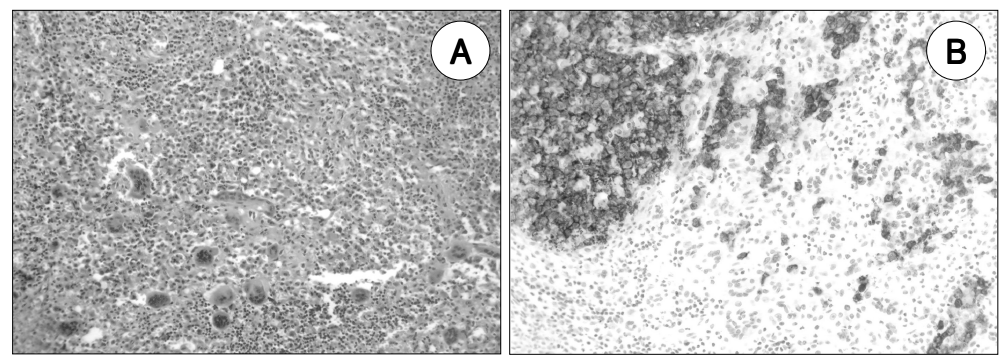

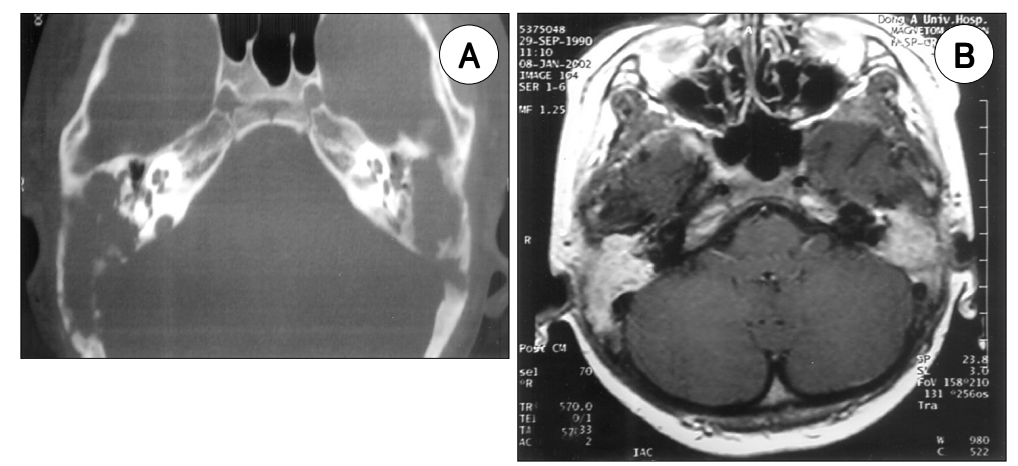

Fig. 3. Preoperative images in case 2. A : Axial temporal bone CT shows massive osteolytic lesion on mastoid area, squamous portion and tegmen. B : Axial Tl-weighted MR image demonstrates a high signal mass lesion in both mastoid portion and middle ear cavity, infiltrating into sigmoid sinus and dura.

서는 중간 정도의 신호강도로 보이는 종물이 관찰되었 고, 조영증강시 비균질성 종물이 뚜렷히 관찰되었다. 그 리고 양측 $\mathrm{S}$ 자형 정맥동과 뇌막으로 침습한 소견도 보 였다(Fig. 3).

측두골 병소 제거를 위해 전신 마취 하에 양측 단순 유양돌기 절제술을 시행하였고 조직검사상 랑게르한스 세 포 조직구증으로 확진되었다. 술 후 다발성 병변을 찾기 위해 시행한 검사에서 골 주사검사 상 양측 유양돌기, 외 이도 및 측두하악관절에 핵종이 흡수가 증가되는 것 외 에 특이 소견은 없었다. 이 후 소아과로 전과되어 7 개월 동안 8차 항암화학요법(etoposide) 을 시행하였고 방사 선 치료는 하지 않았다. 수술 후 2년 6개월째 촬영한 자 기공명촬영 상에서 우측 측두골 내에 재발이나 잔류종 양의 소견은 보이지 않았으며, 합병증이나 재발 소견 없 이 외래 추적 관찰 중이다.

\section{고 찰}

랑게르한스 세포 조직구증의 발병 원인은 현재까지 명 확히 밝혀지지 않고 있으나, 면역학적 이상 반응으로 추 정되고 있다. 병변의 조직병리학적 형태는 단핵구, 호산 구 및 염증세포의 침윤를 보이는 특징적인 염증반응을 나타내며 호산구가 육아조직과 함께 발견되는 것으로 보 아 면역계이상이 원인으로 생각되고 있다.5) 흔히 T 8+ 세포의 감소와 기능 저하, 자가 항체 생산의 증가 등을 동반하기도 한다. ${ }^{3)}$

랑게르한스 세포 조직구증은 주로 15세 미만에서 발 생하며, 약 $50 \%$ 가 5 세 이전에 진단되고, 남자가 여자보 다 약 2 배 가량 많은 것으로 알려져 있다. ${ }^{3) 6)}$ 임상증상
은 매우 다양하나, 약 $80 \%$ 에서 골격계에 침범하며, 특히 5세 이상인 경우 단발성 병변일 수 있다. 골병변은 단독 또는 다발성으로 침범되며 두개골이 가장 흔하다. 다발 병소일 때는 늑골, 대퇴골, 척추, 골반뼈, 하악골, 상완골 순으로 흔하다. ${ }^{3)}$ 병변 부위에서의 임상양상은 무증상이 거나 통증, 국소 종창으로 나타난다. 측두골 침범은 약 $10 \%$ 에서 발견되며 양측성으로 $30 \%$ 까지 보고되고 있 고, ${ }^{2)}$ 이과적 증상만이 나타나는 경우는 $25 \%$ 까지 보고 되었다. ${ }^{6)}$ 측두골에 생기는 경우 골부 외이도를 통해 육 아종이 외이도를 막을 수 있으며 이통, 이루가 흔하고, 2 차 감염으로 인해 중이염, 유양돌기염이 생길 수 있다. 외이도의 파괴, 유양골 피질을 통한 측두골 인상부의 파 괴가 발생할 수 있고, 고실개(tegmen tympani) 를 파괴 하여 뇌막을 침범할 수 있으며 골미로와 안면신경을 침 범하여 각각 내이 증상과 안면신경마비를 일으킬 수 있 다. ${ }^{6)}$ 그 외에 피부, 폐, 간, 조혈 조직, 안구, 치아, 중 추신경계, 뇌하수체 및 시상 하부를 침범할 수 있고, 전 신증상을 나타내기도 한다. ${ }^{3) 6) 7)}$

이 질환은 병리조직학적 진단을 통해 확진되며, 전형 적인 소견은 전자현미경 하에서 세포질 내에 Birbeck granule이 있는 랑게르한스 세포를 포함한 단핵구계열 의 과다증식이다. ${ }^{89)}$ 또한 면역조직화학검사상 CD1a, S- 100 단백, CD4, CD11b, CD11c, EBM11, UCHM1, KB61 및 HLA- DR 양성 반응을 보일 수 있으며,, 림 프구, 과립세포, 단핵구, 호산구의 다양한 증식이 관찰된 다. 본 증례 모두 면역조직화학검사상 CD1a와 S- 100 단백에 양성반응을 보여 랑게르한스 세포 조직구증으로 확진할 수 있었다.

방사선학적으로 두개골 단순촬영에서 경계가 분명한 골 
파괴 병변을 관찰할 수 있는데,“ punched out” 골병소 라고 한다. 전산화단층촬영 및 자기공명영상을 통해 해 당 부위 골격계 병변의 정도와 범위를 알 수 있다. ${ }^{9)}$ 본 증례에서 전산화 단층 촬영을 통하여 골병변 범위 정도 를 알 수 있었고 자기공명영상에서는 뇌경막 및 대혈관 침범 여부를 파악할 수 있어 치료 계획을 세우는 데 유 용하였다.

측두골파괴 병변을 보이는 여러 질환과의 감별진단이 필요하다. 진주종성 중이염, 결핵성 골수염, 매독, 단발 성 골낭종, 신경아세포종, 거대 세포종, 다발성 골수종, 전이 신경종, 골육아종, 임파종 및 뇌수막종 등이 이에 속한다. ${ }^{7)}$

단발성 병변인 경우 임상 경과는 일반적으로 양성이 고, 자연 회복의 확률이 높으므로 치료는 최소화해야 하 며 병변의 진행을 막아 자연회복 전에 영구 손상이 되 는 것을 막는 데 주력해야 한다.310)11) 그러므로 치료 원칙은 단발성 병변인 경우 일차적으로 국소 치료를 시 행하며, 전신병변이나 다발성 병변인 경우에는 국소 치 료와 화학요법을 단독 혹은 병합요법으로 사용한다. 과 거 국내에서 발표된 증례의 경우도 이러한 원칙 하에 치료하였음을 보고하였다. ${ }^{13) 14)}$ 증례 1 의 경우 측두골 부위에 국한되어 발생한 단발성 병변으로, 국소적으로 외과적 절제와 방사선 치료을 시행하였다. 증례 2 의 경 우는 측두골 뿐만 아니라 주위 뇌막, $\mathrm{S}$ 자형 정맥동 및 측두하악관절에 침범하였으므로 병소 제거 후 항암 화 학요법 시행하였다. 잔류 종양이나 재발의 경우에는 방 사선 치료가 필요하고 간기능 손상이나 골수 억제가 발생 한 경우에는 적극적인 화학요법이 필요하다. ${ }^{11)}$ 단발성 골병변의 완치율은 치료방법에 상관없이 $90 \%$ 이상으로 알려져 있다. ${ }^{13)}$ 랑게르한스 세포 조직구증의 외과적 절 제술시 종양의 절제연을 확인할 필요가 없고, 광범위절 제로 완전절제의 효과를 나타낼 수 있다. 치료 방법의 선택은 환자의 임상양상 및 연령을 고려한 후에 외과적 절제, 항암화학요법이나 방사선 치료를 받음으로써, 여 러 가지 위험성과 이점을 고려하여 선택되어야 한다. ${ }^{3)}$

예후는 증상 발현시 나이가 어릴수록(2세 미만), 침범 된 기관이 많을 수록, 조직학적으로 섬유화나 괴사가 많 을수록, 병변의 진행이 빠른경우, 간, 폐, 조혈기관 등의
주요 기관 부전이 있으면 나쁘다. ${ }^{3) 11)}$ 재발률은 약 $16 \%$ 정도이고, 5년 이상의 추적 관찰이 필요한 것으로 알려 져 있다. 국내에서 보고된 다른 증례에서 추적관찰이 1 년 미만으로 불충분하였으나, ${ }^{13) 14)}$ 저자가 보고한 2예 모 두 수술 후 2년 6 개월째 촬영한 측두골 자기공명영상에 서 재발이나 잔류종양의 소견이 보이지 않았지만, 주기 적인 추적관찰이 계속 필요할 것이다.

중심 단어 : 랑게르한스 세포 조직구증. 측두골. 수술 요법.

\section{REFERENCES}

1) Farber S. The nature of "solitary or eosinophilic granuloma" of bone. Am J Pathol 1941;17:625.

2) Lichtenstein L. Histiocytosis X: Integration of eosinophilic granuloma of bone, Letterer-Siwe diease, and Hand-Schuller-Christian disease as related manifestations of a single nosologic entity. AMA Arch Pathol 1953;56:84-102.

3) Ladisch S. Histiocytosis syndrome of childhood. In: Behrman RE, Kliegman RM, Jenson HB, editors. Nelson textbook of pediatrics. 17th ed. Behrman: Saunders;2004. p.1728-35.

4) Willman CL. Langerhans' cell histiocytosis (histiocytosis X): A clonal proliferative disease. New Engl J Med 1994; 331:154-60.

5) Toohill RJ, Kidder TM, Eby LG. Eosinophilic granuloma of the temporal bone. Laryngoscope 1973;83:877-89.

6) Cunningham MJ, Curtin HD, Jaffe R, Stool SE. Otologic manifestations of Langerhans' cell histiocytosis. Arch Otolaryngol Head Neck Surg 1989;115:807-13.

7) Sweet RM, Kornblut AD, Hyams VJ. Eosinophilic granuloma in temporal bone. Laryngoscope 1979;89:1545-52.

8) Hall PA, O'Doherty CJ, Levison DA. Langerhan's cell histiocytosis: An unusual case illustrating the value of immunohistochemistry in diagnosis. Histopathology 1988;12:458

9) Kleinjung T, Woenckhaus M, Bachthaler M, Wolff JE, Wolf SR. Langerhans' cell histiocytosis with bilateral temporal bone involvement. Am J Otolaryngol 2003;24:265-70.

10) Starling KA. Chemotherapy of histiocytosis-X. Hematol Oncol Clin North Am 1987;1:119-22.

11) Postovsky S, Daitzchman M, Dale A, Elhasid R, Ben Arush MW. Unusual presentation of mastoid eosinophilic granuloma in a young patient. Pediatr Hematol Oncol 2001; 18:283-9.

12) Lahey ME. Prognostic factors in histiocytosis $X$. Am J Pediatr Hematol Oncol 1981;3:57-60.

13) Chang KH, Moon SH, Kim HJ, Park HR. A case of eosinophilic granuloma of the temporal bone. Korean J Otolaryngol 2002;45:169-73.

14) Cho YB, Kim HJ, Lee JH, Lim HJ. A case of Langerhans cell histiocytosis of bilateral temporal bone. Korean J Otolaryngol 2001;44:206-8 